\title{
PERILAKU NURI BAYAN (Eclectus roratus) TERHADAP PERUBAHAN KOMPOSISI KOLONI DENGAN USIA YANG BERBEDA
}

\section{THE BEHAVIOR OF ECLECTUS PARROT (Eclectus roratus) ON THE CHANGES OF COLONY COMPOSITION WITH VARIOUS AGES}

\author{
Sari Rahmah Handayani ${ }^{* *}$, Rini Rachmatika ${ }^{2 *}$, Siti Nuramaliati Prijono ${ }^{2}$, Zuliyati Rohmah $^{1}$, \\ Suparno $^{2}$, Umar Sofyani ${ }^{2}$ \\ ${ }^{1}$ Fakultas Biologi, Universitas Gadjah Mada, Jl. Teknika Selatan, Sekip Utara, Daerah Istimewa Yogyakarta, \\ Indonesia 55281, Email: Sarirahmahhandayani239@gmail.com \\ ${ }^{2}$ Bidang Zoologi, Pusat Penelitian Biologi LIPI Jl. Raya Jakarta-Bogor Km.46, Cibinong 16911 \\ E-mail: r.rachmatika@gmail.com \\ *Kontributor utama
}

(diterima Februari 2021, direvisi Mei 2021, disetujui Juli 2021)

\begin{abstract}
ABSTRAK
Penangkaran penting dilakukan untuk mencegah kepunahan burung bayan yang dilindungi dan banyak dimanfaatkan. Pemeliharaan menentukan keberhasilan dari program penjodohan burung. Salah satunya, pola koloni atau pola pasangan. Selain itu, keberhasilan penangkaran tidak lepas dari aspek pakan dan perilaku. Tujuan penelitian ini, yaitu untuk mengetahui respon koloni nuri bayan terhadap penambahan bayan jantan dewasa yang ditinjau dari aspek perilaku dan pakan. Variabel yang diamati adalah perilaku harian, preferensi pakan, serta konsumsi pakan koloni nuri bayan sebelum dan setelah penambahan bayan jantan dewasa. Nuri bayan yang digunakan sebanyak enam ekor yang terdiri dari 2 ekor jantan dan 4 ekor betina. Pengamatan perilaku harian koloni burung bayan dilakukan di Penangkaran Burung, Pusat Penelitian Biologi-LIPI dengan metode scan sampling dan pencatatan dengan metode instantaneous recording. Pengamatan dilakukan selama 16 hari dengan 2 periode, yaitu kontrol dan perlakuan penambahan bayan jantan ( 8 hari kontrol dan 8 hari perlakuan) mulai pukul 07.30-15.30 WIB. Penentuan preferensi dan jumlah konsumsi pakan dilakukan dengan penimbangan sisa setiap jenis pakan. Rata-rata suhu dan kelembaban masing-masing pada pukul 07.30 WIB yaitu 25.78 ${ }^{\circ} \mathrm{C}$ dan $65.00 \%$, pada pukul 12.00 WIB yaitu $31.65{ }^{\circ} \mathrm{C}$ dan $42.83 \%$, serta pada pukul 15.30 WIB yaitu $30.65{ }^{\circ} \mathrm{C}$ dan $44.83 \%$. Koloni burung bayan dengan perlakuan memiliki frekuensi perilaku bertengger, makan, terbang, memanjat, dan interaksi sosial yang lebih tinggi dibandingkan dengan koloni bayan kontrol. Total rata-rata bahan pakan yang dikonsumsi koloni bayan kontrol berdasarkan berat kering sebanyak 145,24 g/koloni/hari, sedangkan pada koloni dengan perlakuan sebesar 154,56 g/koloni/hari. Bahan pakan yang paling disukai oleh koloni bayan adalah jagung dan jumlah konsumsi pakan koloni bayan perlakuan lebih tinggi dibandingkan dengan koloni bayan kontrol.
\end{abstract}

Kata kunci: ethogram, instantaneous recording, konsumsi pakan, perilaku harian, scan sampling.

\begin{abstract}
Captive breeding is important to prevent the extinction of parrots like eclectus parrot. Breeding technique is critical to the success of matchmaking program. One of techniques is colony pattern or pair pattern. In addition, the success of captivity can not be separated from the aspects of feed and behavior. The purpose of this study was to determine the response of parrot colonies to the addition of adult male parrots in terms of behavior and feed aspects. The variables observed were daily behavior, feed preference and feed consumption of parrot colonies before and after the addition of adult male parrots. There were six observed parrots, consisting of 2 males and 4 females. Observation of the daily behavior of parrot colonies was carried out at the bird captive breeding facility, Research Center of Biology-LIPI using the scan sampling method and recording using the instantaneous recording method. Observations were carried out for 16 days with 2 periods, namely control and treatment of addition of male parrots ( 8 days of control and 8 days of treatment) starting at 07.30-15.30 (GMT+7). The determination of preferences and the amount of feed consumption were carried out by weighing the remaining feed for each type of feed. The average temperature and humidity were $25.78{ }^{\circ} \mathrm{C}$ and $65.00 \%$ at $07.30 \mathrm{AM}, 31.65^{\circ} \mathrm{C}$ and $42.83 \%$ at $12.00 \mathrm{PM}, 30.65{ }^{\circ} \mathrm{C}$ and $44.83 \%$ at $3.30 \mathrm{PM}$. The treated parrot colonies had higher frequency of perching, eating, flying, climbing and social interaction than the control parrot colonies. The total average of feed consumed by the control parrot colonies was $145.4 \mathrm{~g} /$ colony/day, while in the treated colonies was $154.56 \mathrm{~g} /$ colony/day. The most preferred feed was corns and the amount of feed consumption of the treated parrot colonies was higher than that of the control parrot colony.
\end{abstract}

Keywords: ethogram, instantaneous recording, feed consumption, daily behavior, scan sampling.

\section{PENDAHULUAN}

Jumlah spesies burung di Indonesia sekitar $17 \%$ dari total spesies burung di dunia, yaitu 1351 spesies dan 397 endemik (Setyowati dkk. 2008). Salah satu dari spesies burung tersebut adalah nuri bayan (Eclectus 
roratus, Müller 1776). Burung bayan adalah salah satu contoh burung dengan dimorfisme seksual. Bayan betina memiliki bulu tubuh dominan merah, merah dengan biru, atau merah dengan biru keunguan, tergantung dari anak jenisnya, sedangkan bayan jantan hampir keseluruhan berwarna hijau (Arndt 1986). Beberapa pendapat mengenai pengelompokkan anak jenis nuri bayan di antaranya menurut Forshaw (2010) terdapat 9 anak jenis Eclectus roratus di dunia, sedangkan Juniper \& Parr (1998) melaporkan terdapat 10 anak jenis. Adapun menurut IOC World Bird List Version 10.2 (Gill et al. 2020) hanya terdapat delapan anak jenis. Burung bayan tersebar di dataran rendah wilayah Indonesia bagian timur seperti Provinsi Maluku, Maluku Utara, Pulau Sumba, pulaupulau di sekitar Teluk Cendrawasih (Geelvink Bay) Papua, Papua Barat, Papua Nugini, Kepualaun Bismarck, Kepulauan Admiralty, dan di ujung Semenanjung Cape York, Australia (Forshaw 2010).

Keanekaragaman burung di Indonesia terganggu karena adanya perusakan habitat dan perdagangan satwa, terutama pada burung paruh bengkok. Hal tersebut memiliki pengaruh yang besar sehingga dapat mengubah status konservasi ratusan jenis burung menjadi terancam dan genting dalam daftar merah The International Union for Conservation of Nature Red List of Threatened Species (IUCN) (Kartikasari dkk. 2007). BirdLife International (2019) menetapkan nuri bayan berstatus Least Concern (berisiko rendah), namun pada kenyataanya di alam populasi burung nuri bayan semakin berkurang. Menurut Warsito \& Bismark (2010) langkanya burung paruh bengkok seperti bayan di alam disebabkan oleh kerusakan habitat (50\%), tekanan gabungan antara perburuan dan kerusakan habitat $(10 \%)$, perburuan $(5 \%)$, perdagangan $(3 \%)$, habitat yang sempit disertai populasi yang rendah (16\%), dan sebab lain yang tidak diketahui (16\%). Kondisi keterbatasan ketersediaan salah satu pohon sarang burung paruh bengkok, yaitu pohon binong (Tetrameles nudiflora) di hutan yang semakin langka berdampak pula pada ketersediaan lubang sarang yang pada gilirannya dapat membatasi ukuran populasi perkembangbiakan burung paruh bengkok (Beissinger \& Bucher 1992). Keindahan bulu dan suaranya menyebabkan burung bayan banyak diminati. Pemerintah telah melakukan upaya perlindungan burung bayan melalui Peraturan Menteri Lingkungan Hidup dan Kehutanan Republik Indonesia Nomor P.106/Menlhk/Setjen/ Kum.1/12/2018 tentang Perubahan Kedua Atas Peraturan Menteri Lingkungan Hidup dan Kehutanan Nomor P.20/Menlhk/Setjen/ Kum.1/6/2018 tentang Jenis Tumbuhan dan Satwa yang Dilindungi. Konservasi eks situ sangat berperan dalam mencegah perdagangan satwa secara ilegal sekaligus memenuhi permintaan pasar.

Pakan dan perilaku satwa merupakan salah satu aspek yang harus diperhatikan dalam manajemen penangkaran. Pengetahuan mengenai pakan dan perilaku burung bayan menunjang keberhasilan penangkaran nuri bayan. Jenis pakan yang digemari burung bayan, yaitu biji-bijian, buah pada kanopi pepohonan, dan jarang memakan tanaman pangan yang dimiliki penduduk di habitat aslinya (Beehler dkk. 2001). Selain itu, burung bayan di alam juga suka memakan kacangkacangan, buah beri, dan tunas daun (Forshaw \& Cooper 1989). Menurut Bailey (1984) kualitas dan kuantitas pakan yang dibutuhkan oleh satwa sangat tergantung pada jenis kelamin, umur, jenis satwa, fungsi fisiologi, 
musim, cuaca, dan letak geografis. Jenis pakan burung bayan dewasa yang disarankan di penangkaran menurut Garsetiasih \& Takandjandji (2006) di antaranya berupa kacang tanah, kacang panjang, kangkung, dan pepaya. Penelitian lain yang dilakukan oleh Takandjanji dan Sutrisno (2011) menyebutkan bahwa jenis pakan burung bayan dewasa di penangkaran adalah jagung (tua dan muda), kacang hijau, kacang tanah, kacang turis, kacang panjang, pisang, pepaya, kangkung, tomat, dan wortel serta tambahan vitamin.

Burung bayan diketahui hidup dalam kelompok kecil atau berpasangan di dalam kawasan hutan di pucuk-pucuk pohon tinggi (Alamendah 2011). Hasil pengamatan Forshaw (2010) terhadap burung bayan di habitat alaminya di hutan hujan tropis dan dataran rendah diketahui bahwa burung bayan terlihat bergerak sendirian, berpasangan, atau dalam kelompok besar. Dalam menangkarkan suatu jenis satwa seringkali terdapat suatu kendala, misalnya pasangan yang tidak berjodoh, keterbatasan kandang, maupun perkelahian dalam koloni. Kendala tersebut harus dapat diatasi dengan merujuk pada kebiasaan burung tersebut di habitat alaminya. Kandang yang terbatas membuat satwa harus berada dalam satu kandang membentuk suatu koloni. Menurut Magno (2015) kandang sangat mempengaruhi kesejahteraan dari satwa tersebut karena beberapa burung membutuhkan area latihan. Selain itu, terbatasnya ruang gerak memicu terjadinya obesitas, apalagi jika diiringi pemberian pakan yang berenergi tinggi. Aspek perilaku dari koloni bayan harus menjadi perhatian karena akan menentukan apakah satwa tersebut dapat beradaptasi menjadi satu koloni atau tidak. Menurut Minias dkk. (2020) ukuran koloni sangat berhubungan dengan strategi mencari makan, respon terhadap predator, dan interaksi sosial. Tujuan penelitian ini adalah untuk mengetahui perilaku burung bayan terhadap perubahan komposisi koloni, yaitu dengan penambahan bayan dewasa yang ditinjau dari aspek perilaku dan pakan.

\section{METODE PENELITIAN}

Pengamatan dilaksanakan di Penangkaran Burung, Pusat Penelitian Biologi-LIPI Cibinong pada bulan Juli 2019. Kandang nuri bayan berukuran $650 \times 400 \times 300 \mathrm{~cm}$ yang dilapisi oleh kawat berukuran $0,5 \times 0,5 \mathrm{~cm}$. Di dalam kandang burung nuri bayan terdapat tenggeran dengan diameter 3-5 $\mathrm{cm}$, tempat pakan, tempat minum, tempat mandi, dan sangkar berukuran $70 \times 43 \times 52 \mathrm{~cm}$. Nuri bayan yang digunakan sebanyak enam ekor yang terdiri dari 2 ekor jantan dan 4 ekor betina. Pengamatan perilaku harian dilakukan dengan metode scan sampling dan pencatatan dengan metode instantaneous recording (Martin \& Bateson 2007). Pengamatan dilakukan selama 16 hari, yaitu kontrol (K0) dan perlakuan penambahan bayan jantan (K1) ( 8 hari kontrol dan 8 hari perlakuan) mulai pukul 07.30-15.30 WIB. Penentuan preferensi dan jumlah konsumsi pakan dilakukan dengan penimbangan sisa setiap jenis pakan. Kandungan nutrien bahan pakan dianalisis di Laboratorium Nutrisi, Pusat Penelitian Biologi-LIPI.

Perilaku yang diamati, yaitu makan, eliminasi, interaksi sosial, bersuara (vokalisasi), bertengger, berjalan, memanjat, terbang, dan merawat tubuh. Interaksi sosial terdiri dari agonistik atau perilaku menyerang, bercumbu, dan allofeeding. Perilaku merawat tubuh terdiri dari membersihkan paruh, preening, menggetarkan bulu, dan meregangkan tubuh. Pengamatan nuri bayan dibagi menjadi dua kelompok, yaitu koloni kontrol (K0) terdiri dari satu bayan 
jantan umur dua tahun dengan kondisi cacat pada sayap, tiga bayan betina berumur dua tahun, dan satu bayan betina berumur satu tahun. Koloni perlakuan (K1) terdiri atas individu K0 dengan penambahan satu bayan jantan baru berumur empat tahun dari kandang lain ke dalam koloni burung bayan kontrol sehingga jumlah koloni bayan pada kandang menjadi enam individu. Pengukuran kelembaban dan suhu pada kandang dilakukan dengan termohigrometer setiap hari selama pengamatan pada pukul 07.30 WIB, 12.00 WIB, dan 15.30 WIB. Pemberian pakan burung bayan dilakukan pada pagi hari sebelum pukul 07.30 WIB. Pemberian pakan dilakukan secara kafetaria dan ad libitum. Penimbangan pakan dan sisa pakan dilakukan dengan timbangan analitik digital ketelitian 0,01 g. Pakan yang diberikan terdiri dari jagung, jambu biji, biji bunga matahari, pisang kepok, tauge, kelapa, wortel, kangkung, kacang panjang, dan telur ayam rebus. Konsumsi pakan diperoleh dengan cara mengurangi jumlah pakan yang diberikan dengan jumlah pakan yang tersisa. Penimbangan pakan dilakukan pada pagi hari saat pemberian pakan dan keesokan harinya untuk penimbangan pakan yang tersisa. Data yang diperoleh dianalisis secara deskriptif. Data perilaku harian bayan diolah menggunakan rumus frekuensi perilaku (Altmann 1974) sebagai berikut:

Frekuensi perilaku $=\frac{X}{Y} \times 100 \%$

Keterangan:

$\mathrm{X}=$ Jumlah suatu perilaku selama waktu pengamatan.

$\mathrm{Y}=$ Jumlah seluruh perilaku selama waktu pengamatan.

\section{HASIL DAN PEMBAHASAN}

\section{Perilaku Harian}

Perilaku koloni burung nuri bayan yang teramati terdiri atas sembilan kategori, yaitu makan, eliminasi, interaksi sosial, bersuara (vokalisasi), bertenger, berjalan, memanjat, terbang, dan merawat tubuh. Interaksi sosial terdiri dari agonistik atau perilaku menyerang dan allofeeding. Perilaku merawat tubuh terdiri dari merentangkan sayap, menelisik bulu, membersihkan paruh, dan menggetarkan bulu (Tabel 1). Koloni burung nuri bayan kontrol terdiri dari lima individu, yaitu satu betina umur satu tahun, tiga betina umur dua tahun, dan satu jantan umur dua tahun. Kondisi koloni burung nuri bayan sehat, namun bayan jantan tersebut mengalami cacat permanen pada sayap sejak lahir sehingga tidak dapat terbang. Burung bayan betina umur satu tahun memiliki kondisi bulu ekor yang lepas karena tersangkut sangkar dan diserang oleh burung bayan yang lebih tua. Suhu rata-rata dan kelembaban selama pengamatan masingmasing pada pukul $7.30 \mathrm{WIB}$, yaitu $25.78^{\circ} \mathrm{C}$ dan $65.00 \%$; pada pukul 12.00 WIB, yaitu $31.65{ }^{\circ} \mathrm{C}$ dan $42.83 \%$; serta pada pukul 15.30 WIB, yaitu $30.65^{\circ} \mathrm{C}$ dan $44.83 \%$.

Hasil pengamatan menunjukkan bahwa perilaku yang paling sering dilakukan nuri bayan baik kelompok K0 maupun K1 adalah bertengger, namun frekuensi bertengger kelompok K1 lebih tinggi (50,92\%) dibanding K0 $(38,49 \%)$, terdapat selisih frekuensi sebesar $11,71 \%$. Aktivitas kedua yang paling sering dilakukan kedua kelompok adalah makan, sedangkan perilaku yang paling jarang dilakukan adalah eliminasi (Gambar 1). Frekuensi makan, memanjat, terbang, dan interaksi sosial lebih banyak dilakukan kelompok K0 dibandingkan kelompok K1. Sebaliknya, frekuensi 
Tabel 1. Ethogram aktivitas pada burung bayan.

\begin{tabular}{|c|c|c|c|}
\hline No. & Perilaku & Aktivitas & Keterangan \\
\hline 1. & Makan & Makan & $\begin{array}{l}\text { Mematuk, mengupas kulit biji dengan paruh, } \\
\text { mengambil isi biji, mengunyah, menelan. } \\
\text { Mengambil pakan dengan kaki, memasukkan ke } \\
\text { dalam paruh, mengupas kulit biji, memakan isi } \\
\text { biji, mengunyah, menelan. }\end{array}$ \\
\hline 2. & Eliminasi & $\begin{array}{l}\text { Perilaku membuang } \\
\text { kotoran }\end{array}$ & $\begin{array}{l}\text { Bertengger, mengangkat bagian ekor, mengejan, } \\
\text { mengeluarkan ekskreta, menurunkan bagian ekor. }\end{array}$ \\
\hline \multirow[t]{4}{*}{3.} & \multirow[t]{4}{*}{ Interaksi Sosial } & Allopreening & $\begin{array}{l}\text { Mendekat, membersihkan bulu burung individu } \\
\text { lain dengan paruh. }\end{array}$ \\
\hline & & Allofeeding & $\begin{array}{l}\text { Mendekati individu lain, mengadukan paruh, } \\
\text { individu lain mendekam sambil membuka } \\
\text { paruhnya, mengeluarkan pakan ke dalam paruh } \\
\text { individu lain. }\end{array}$ \\
\hline & & Agonistik & $\begin{array}{l}\text { Mematuk, mengusir individu lain yang mendekat } \\
\text { dengan suara keras dan merentangkan sayap. }\end{array}$ \\
\hline & & Bercumbu & $\begin{array}{l}\text { Berjalan mendekati pasangan, menggesekkan } \\
\text { kepala ke bulu leher pasangan, paruh bertautan. }\end{array}$ \\
\hline 4. & Vokalisasi & Vokalisasi & Bertengger, mengeluarkan suara. \\
\hline 5. & Bertengger & Bertengger & $\begin{array}{l}\text { Berdiri di atas kayu atau besi, mengangkat kedua } \\
\text { sayap, diam. } \\
\text { Berdisi di atas kayu atau besi, mengangkat salah } \\
\text { satu sayap dan kaki ke belakang, diam. } \\
\text { Terbang, hinggap di dinding kawat, diam. } \\
\text { Berjalan, memanjat di dinding kawat kandang, } \\
\text { diam. }\end{array}$ \\
\hline 6. & Berjalan & Berjalan & $\begin{array}{l}\text { Melangkahkan kaki bergantian, berpindah tempat. } \\
\text { Melangkahkan kaki, menjaga keseimbangan } \\
\text { dengan mengaitkan paruh ke titian, berpindah } \\
\text { tempat. }\end{array}$ \\
\hline 7. & Memanjat & Memanjat & $\begin{array}{l}\text { Mengaitkan paruh pada dinding kawat, disusul } \\
\text { dengan kaki menaikki kawat, berpindah tempat. }\end{array}$ \\
\hline 8. & Terbang & Terbang & $\begin{array}{l}\text { Bertengger, mendorong tubuh (condong ke depan), } \\
\text { mengepakkan sayap. } \\
\text { Bertengger, mendorong tubuh, mengepakkan sayap, } \\
\text { bersuara. }\end{array}$ \\
\hline \multirow[t]{3}{*}{9.} & \multirow[t]{3}{*}{ Merawat Tubuh } & Menelisik (preening) & $\begin{array}{l}\text { Bertengger, menggaruk tubuh dengan paruh pada } \\
\text { sela-sela bulu. }\end{array}$ \\
\hline & & Membersihkan paruh & $\begin{array}{l}\text { Bertengger, menggesekkan paruh pada besi atau } \\
\text { kayu. } \\
\text { Bertengger, menggigit kayu atau besi secara berulang. }\end{array}$ \\
\hline & & Menggetarkan bulu & $\begin{array}{l}\text { Bertengger, menggerakkan tubuh sehingga bulu } \\
\text { bergetar. }\end{array}$ \\
\hline
\end{tabular}

merawat tubuh, berjalan, dan vokalisasi lebih banyak ditemui pada kelompok K1 dibanding K0.

Bertengger banyak dilakukan oleh koloni bayan pada pagi hari. Tempat yang biasa digunakan burung bayan bertengger, yaitu di dalam sangkar, di pagar besi, tenggeran kayu di sudut kandang, dan di sudut atas kandang.
Cara bertengger nuri bayan adalah dengan posisi jari kaki menggenggam tempat bertengger, dua jari ke depan dan dua jari ke belakang, sesuai susunan jari kakinya yang bertipe zygodactyl, yaitu dua jari kaki menghadap ke depan (jari ke-2 dan 3) dan dua jari kaki menghadap ke belakang (jari ke-1 dan 4) (Homberger 2006). 


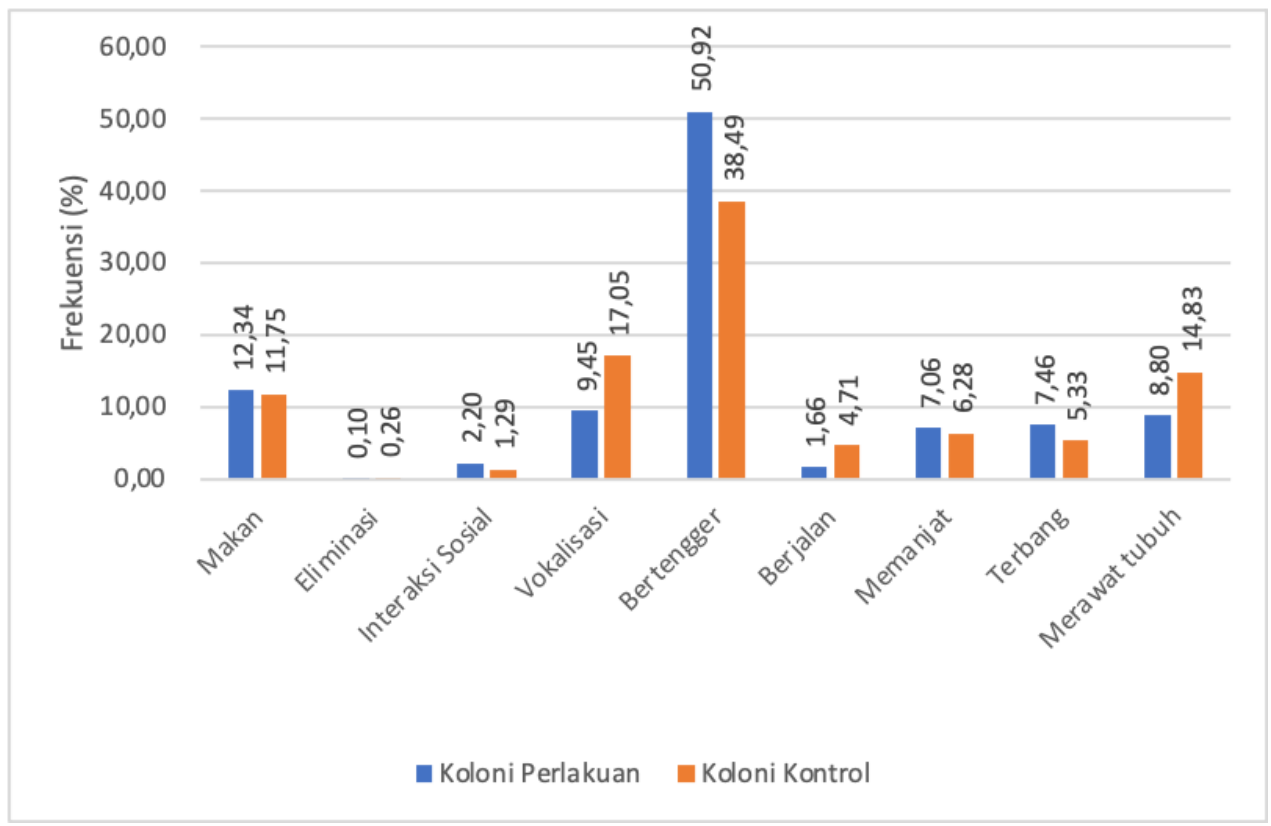

Gambar 1. Frekuensi Perilaku Koloni Burung Bayan Kontrol (K0) dan Perlakuan (K1) di penangkaran.

Burung bayan betina umur satu tahun dominan bertengger di dalam sangkar. Hal tersebut dikarenakan bayan betina tersebut berumur paling muda dan terbiasa berada di dalam sangkar untuk menghindari serangan dari bayan yang lebih tua dan untuk meningkatkan kemampuan beradaptasi. Salah satu burung bayan betina umur dua tahun selalu bertengger di bagian sudut atas kandang, sedangkan burung bayan yang lain biasa bertengger di sudut atas kandang dan di tenggeran sudut kandang. Menjelang siang hari mulai pukul 10.00 WIB hingga siang hari pukul 14.00 WIB burung bayan aktif melakukan perilaku makan, vokalisasi, merawat tubuh, dan terbang. Berdasarkan Revilia dkk. (2017) perilaku bertengger burung nuri bayan lebih dominan dibandingkan dengan perilaku lain, yaitu hingga 55\% dari keseluruhan perilaku harian. Hal tersebut sesuai dengan hasil pengamatan dalam penelitian ini di mana perilaku bertengger memiliki frekuensi perilaku paling tinggi baik pada K0 $(38,49 \%)$ maupun pada K1 $(50,92 \%)$.
Perilaku bertengger lebih dominan dilakukan oleh koloni dengan perlakuan. Perilaku tersebut dilakukan sebagai bentuk kewaspadaan sekaligus adaptasi terhadap individu bayan jantan yang baru ditambahkan. Bertengger juga dilakukan oleh individu bayan jantan umur empat tahun terhadap koloni burung bayan yang ada. Menurut Takandjandji dkk. (2010) burung jantan lebih banyak bertengger dibandingkan burung betina dengan tujuan pengawasan terhadap lingkungan, karena pada umumnya burung jantan mempunyai sifat melindungi, lebih agresif, dan lebih berani terhadap gangguan dibandingkan dengan burung betina. Adaptasi tersebut hanya berlangsung selama satu hari karena di hari berikutnya koloni burung bayan dan individu burung bayan jantan umur empat tahun sudah mulai membaur, ditandai dengan meningkatnya frekuensi interaksi sosial yang ada. Interaksi sosial yang dilakukan, yaitu allopreening, bermain, dan allofeeding. Interaksi tersebut dilakukan antara bayan jantan umur empat tahun dengan bayan betina umur dua tahun 
dan satu tahun. Aktivitas bermain ditandai dengan terbang dan memanjat bersama. Burung bayan jantan umur empat tahun cenderung lebih suka menghampiri burung bayan betina umur dua tahun yang berada di sudut atas kandang dan menghampiri burung bayan betina umur satu tahun di dalam sangkar. Burung bayan jantan umur empat tahun tersebut selalu didekati atau diikuti oleh burung bayan betina yang lain, namun burung bayan jantan tersebut selalu menghindar.

Perilaku makan adalah perilaku yang berpengaruh langsung terhadap perkembangbiakan satwa di penangkaran atau di habitat aslinya (Alikodra 1990). Perilaku makan dilakukan dengan terbang atau berjalan ke arah tempat pakan, kemudian burung bayan bertengger di tatakan pakan. Burung bayan mematuk makanan dengan paruh dan terkadang mengambil makanan dengan kaki, kemudian dimasukkan ke dalam paruh. Berdasarkan Takandjandji dkk. (2010) pada saat makan, paruh burung terbuka dan ujung lidahnya yang berbentuk sikat menarik makanan, kemudian lidahnya ditarik kembali ke dalam paruh, dihancurkan menggunakan paruh dan lidah, dan ditelan. Begitu pula yang teramati dalam penelitian ini, bentuk paruh bayan yang melengkung memudahkan untuk memakan biji-bijian. Pakan berupa biji-bijian seperti biji bunga matahari, kacang panjang, dan jagung harus dikupas terlebih dahulu dengan paruhnya, kemudian burung bayan memakan isi bijinya. Cara yang sama dilakukan Burung bayan ketika mengonsumsi telur ayam rebus yang masih terlindungi oleh cangkang. Frekuensi makan pada K1 lebih tinggi $(12,34 \%)$ daripada K0 (11,75\%) karena jumlah individu bertambah pada K1.
Bertambahnya individu tersebut meningkatkan persaingan antar individu sehingga Ketika burung bayan jantan umur empat tahun makan, maka beberapa saat kemudian datang burung bayan yang lain untuk makan. Menurut Desmudzat dkk. (2015) terdapat persaingan pada saat makan jika jantan memiliki pesaing jantan yang lain pada satu kandang, namun tidak terdapat perbedaan yang cukup signifikan pada frekuensi makan dari para pejantan tersebut.

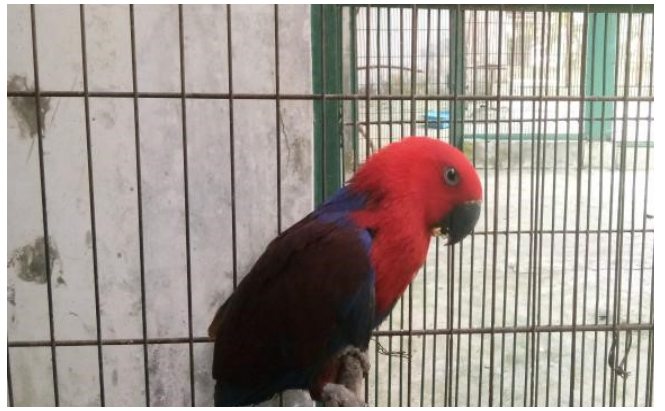

Gambar 2. Burung Bayan Betina Umur Satu Tahun (Dokumen Pribadi 2019).

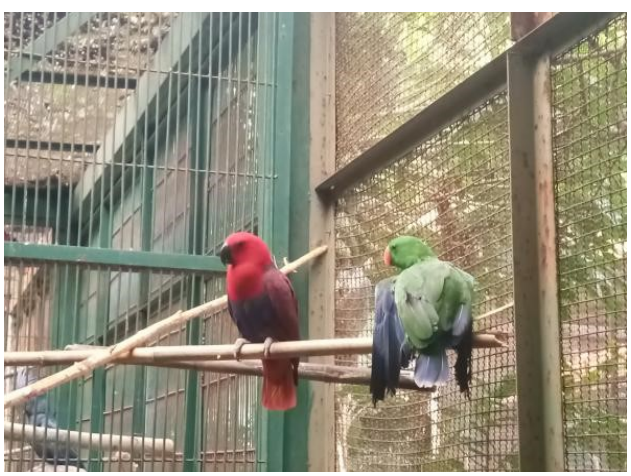

Gambar 3. Burung Bayan Jantan dan Betina Umur Dua Tahun (Dokumen Pribadi 2019).

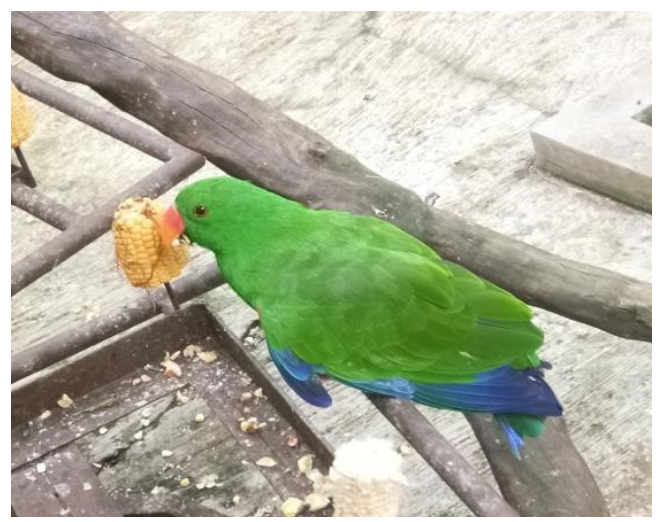

Gambar 4. Burung Bayan Jantan Umur Empat Tahun (Dokumen Pribadi 2019). 


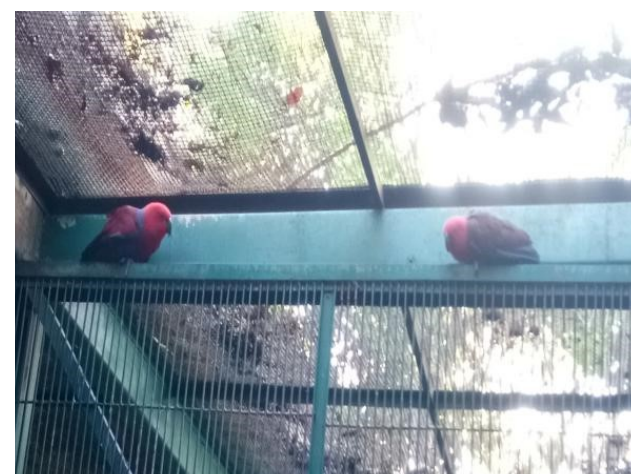

Gambar 5. Burung Bayan Betina Umur Dua Tahun di Sudut Atas Kandang (Dokumen Pribadi 2019).

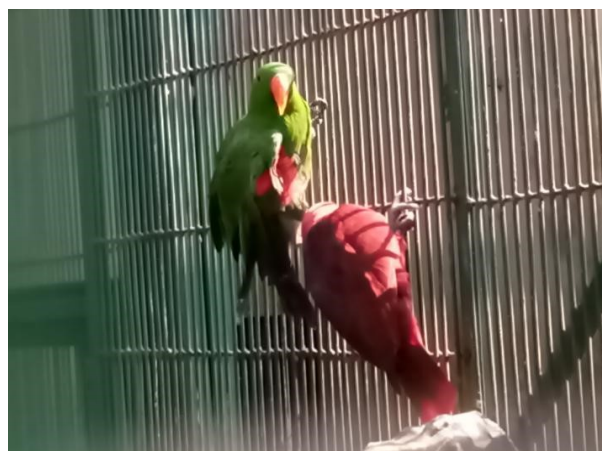

Gambar 6. Burung Bayan Jantan dan Betina Umur Dua Tahun Memanjat Dinding Pagar Besi (Dokumen Pribadi 2019).

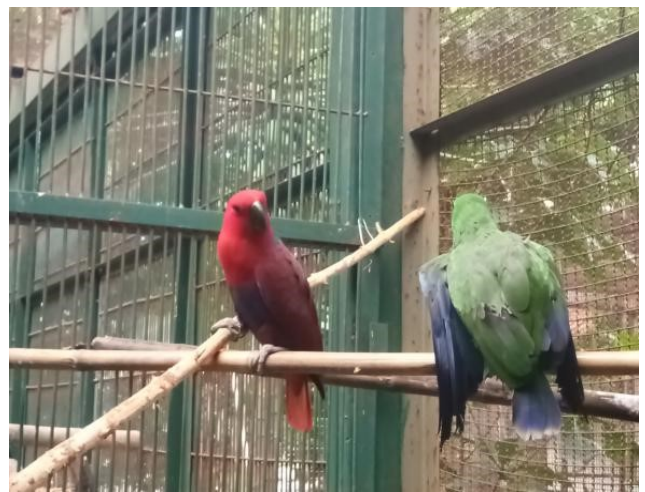

Gambar 7. Burung Bayan Jantan dan Betina Umur Dua Tahun Bertengger di SudutKandang(Dokumen Pribadi 2019).

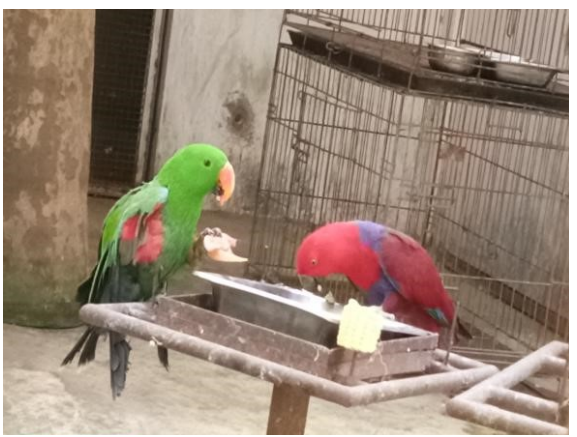

Gambar 8. Burung Bayan Jantan dan Betina Umur Dua Tahun Makan (Dokumen Pribadi 2019).

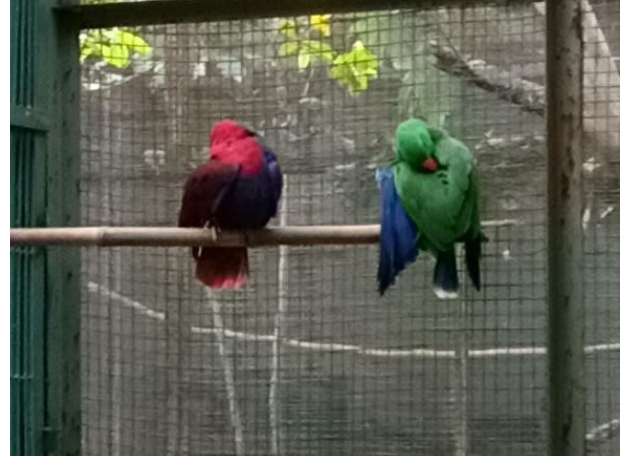

Gambar 9. Burung Bayan Jantan dan Betina Umur Dua Tahun Menelisik (Dokumen Pribadi 2019).

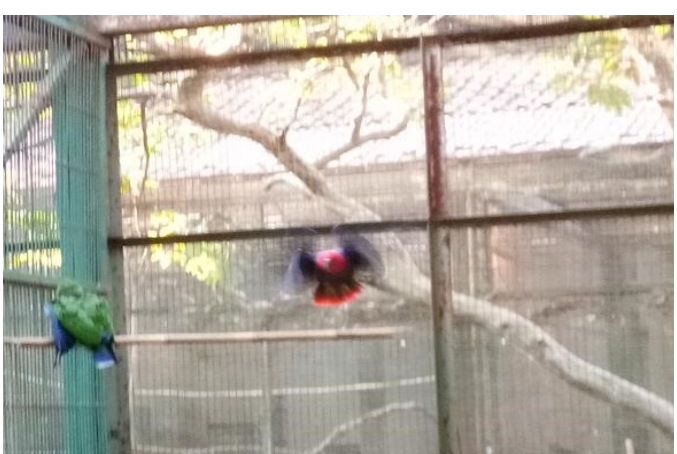

Gambar 10. Burung Bayan Betina Umur Dua Tahun Terbang (Dokumen Pribadi 2019).

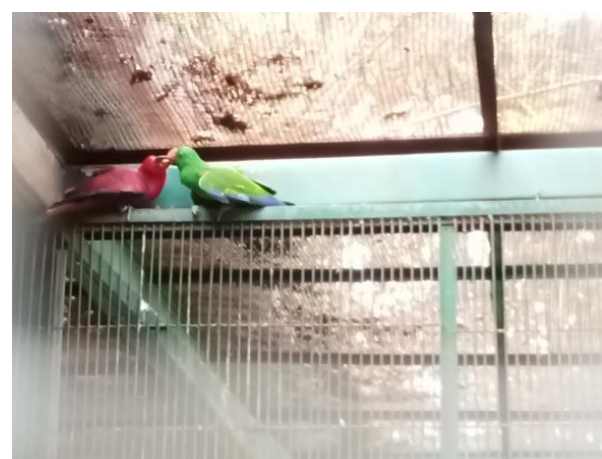

Gambar 11. Allofeeding oleh Bayan Jantan Umur Empat Tahun dengan Bayan Betina Umur Dua Tahun (Dokumen Pribadi 2019).

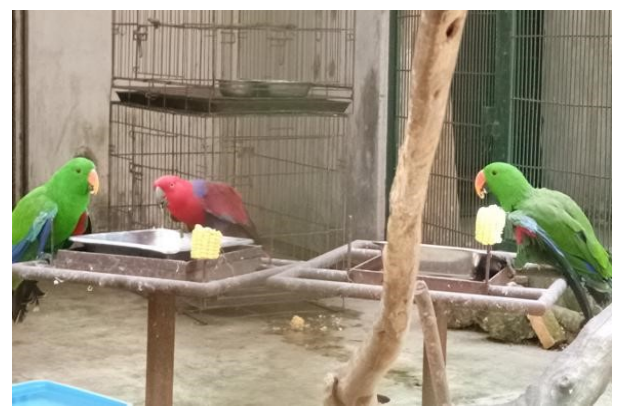

Gambar 12. Burung Bayan Jantan Umur Empat Tahun Makan Bersama dengan Burung Bayan Lainnya (Dokumen Pribadi 2019). 


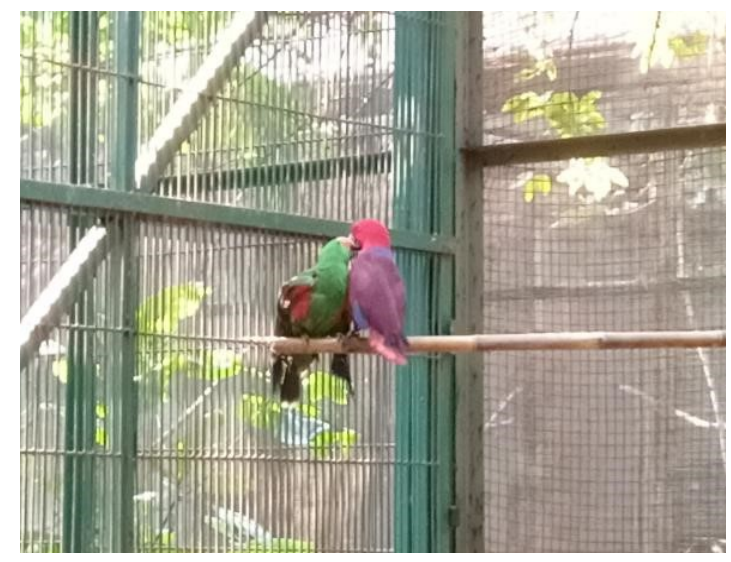

Gambar 13. Burung Bayan Jantan dan Betina Umur Dua Tahun Bercumbu (Dokumen Pribadi 2019).

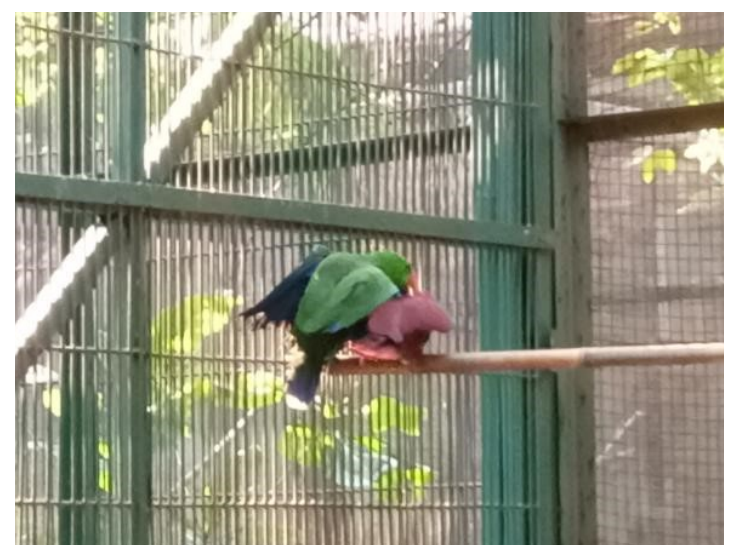

Gambar 14. Burung Bayan Jantan dan Betina Umur Dua Tahun Mating (Dokumen Pribadi 2019).

Suara merupakan salah satu bentuk komunikasi antara individu satu dengan yang lain. Di habitatnya, betina melakukan vokalisasi saat awal musim kawin yang sering dilakukan di lubang sarang. Hal ini diduga untuk menandakan kehadirannya (Heinsohn \& Ledge 2003). Pada pengamatan ini, vokalisasi sebagian besar juga dilakukan oleh burung bayan betina, yaitu betina yang berumur dua tahun. Vokalisasi semakin intens ketika terdapat suara dari burung-burung di sekitarnya. Suara yang dihasilkan burung bayan bervariasi. Suara burung bayan terdengar keras seperti graaah, kedek kedek kedek secara berulang, dan terkadang seperti suara lonceng terdengar keleng (van Balen et al. 2015). Ketika burung jantan baru dipindahkan ke dalam kandang, burung jantan baru terbang dan hinggap di dinding kawat. Ketika perlakuan tersebut dilakukan, koloni burung kontrol memberikan respon, yaitu terbang, bertengger, dan bersuara dengan keras. Perilaku vokalisasi tersebut dilakukan oleh semua individu burung bayan pada koloni kontrol dan berlangsung selama dua menit. Setelah itu, koloni burung bayan bertengger tanpa melakukan perilaku lainnya selama sekitar 10 menit. Pada menit ke-30 koloni burung bayan mulai beradaptasi dengan melakukan aktivitas seperti biasanya, namun dengan frekuensi yang lebih rendah. Pada pengamatan ini, frekuensi vokalisasi pada K1 lebih rendah (9,45\%) dari K0 (17,05\%). Begitu pula yang terjadi dengan aktivitas merawat tubuh. Frekuensi merawat tubuh pada K0 lebih tinggi $(14,83 \%)$ daripada K1 $(8,80 \%)$. Merawat tubuh yang sering dilakukan yaitu preening, membersihkan paruh, meregangkan tubuh, dan menggetarkan bulu. Aktivitas preening atau menelisik dilakukan dengan menggunakan paruhnya. Lebih rendahnya frekuensi vokalisasi dan merawat diri pada $\mathrm{K} 1$ daripada K0 mungkin disebabkan karena kehadiran jantan baru sehingga frekuensi bertengger sebagai salah satu bentuk pengawasan terhadap lingkungan sekitar meningkat pada K1. Aktivitas bertengger dan merawat diri banyak dilakukan pada sore hari sekitar pukul 14.00 WIB-15.30 WIB.

Pergerakan yang dilakukan burung di penangkaran di antaranya terbang, memanjat, dan berjalan. Perilaku terbang dilakukan oleh burung bayan dari satu sisi pagar ke sisi pagar lainnya atau dari tempat bertengger ke tempat pakan. Kemampuan terbang pada burung dalam kandang penangkaran mempunyai keterbatasan. Kandang yang sempit tidak 
memungkinkan burung bayan melakukan aktivitas terbang dalam waktu yang lama. Setelah burung terbang biasanya diikuti dengan perilaku memanjat di dinding kandang yang berupa anyaman kawat atau besi. Perilaku terbang terkadang juga disertai dengan vokalisasi. Frekuensi perilaku terbang juga lebih tinggi pada K1 (7,46\%) daripada K0 $(5,33 \%)$. Hal tersebut dapat disebabkan karena burung masih dalam tahap mengamati keadaan sekitar sehubungan dengan penambahan bayan jantan. Selain itu, lingkungan di sekitar kandang burung sering terlihat ular melintas di mana ular adalah musuh alami bagi burung. Pada penelitian yang dilakukan oleh Carrete \& Tella (2015) menunjukkan hasil bahwa hilangnya respon antipredator dan kemampuan melarikan diri pada burung penangkaran dibandingkan dengan yang ditangkap di alam liar. Takandjandji dkk. (2010) melaporkan bahwa jika terdapat gerakan yang mencurigakan, maka secara otomatis burung langsung terbang sambil mengeluarkan suara keras.

Aktivitas berjalan dilakukan burung bayan dengan kakinya dan terkadang dibantu dengan paruhnya untuk menjaga keseimbangan. Frekuensi berjalan pada K0 (4,71\%) lebih tinggi dari pada K1 (1,66\%). Hal ini dimungkinkan karena pada K0 ruang gerak lebih luas daripada K1 sehingga burung lebih leluasa untuk melakukan perpindahan. Burung bayan biasanya berjalan di atas tenggeran berupa batang atau ranting kayu dan besi di bagian atas kandang. Burung bayan memanjat dengan menggunakan bantuan paruh dan kakinya. Susunan kaki zygodactyl yang dimiliki bayan ini memudahkan bayan untuk mahir memanjat dan menggenggam makanan (Prijono dkk 2020). Paruh digunakan untuk menjangkau besi atau kawat diatasnya kemudian disusul dengan gerakan kaki yang memanjat. Frekuensi memanjat pada K0 lebih rendah $(6,28 \%)$ dari K1 $(7,06 \%)$.

Interaksi sosial yang dilakukan koloni burung bayan kontrol di antaranya allofeeding, bercumbu, dan agonistik berupa mematuk. Frekuensi perilaku interaksi sosial pada K0 lebih rendah $(1,29 \%)$ daripada K1 $(2,20 \%)$. Allofeeding dilakukan oleh burung bayan jantan terhadap betina dan burung bayan betina terhadap betina dengan cara memberikan makanan melalui paruh. Bercumbu dilakukan oleh burung bayan jantan terhadap burung bayan betina. Bercumbu biasanya dilakukan dengan saling mendekatkan paruh jantan dan betina tanpa adanya aktivitas makan, atau dengan saling menelisik pada bulu di sekitar leher dan kepala. Perilaku agonistik berupa mematuk dan mengeluarkan suara yang keras sebagai tanda untuk mengusir individu bayan yang mendekat. Berkelahi merupakan aktivitas sosial yang agresif, yaitu menggigit burung bayan lainnya (Takandjandji dkk. 2010). Berdasarkan pengamatan, burung bayan jantan dan burung bayan betina umur dua tahun melakukan pendekatan dengan selalu melakukan aktivitas secara bersama atau berdekatan seperti makan, bertengger, allofeeding, dan allopreening. Terkadang burung bayan jantan dan betina tersebut melakukan perilaku kawin (mating) ketika bertengger di tenggeran pada sudut kandang. Perilaku mating tersebut ditandai dengan aktivitas bayan jantan mendekati betina, bercumbu, saling mematuk, dan bayan jantan berusaha menaiki bayan betina yang telah merendahkan posisi tubuhnya kemudian melakukan kopulasi. 
Tabel 2. Kandungan bahan kering, nutrien, dan bruto energi pakan bayan (dalam 100\% BK).

\begin{tabular}{|c|c|c|c|c|c|c|c|c|}
\hline \multirow{2}{*}{ Pakan } & $\mathrm{BK}$ & $\mathrm{BO}$ & $\mathrm{Abu}$ & PK & LK & SK & BETN & \multirow{2}{*}{$\frac{\mathrm{GE}}{\mathrm{kal} / \mathrm{g}}$} \\
\hline & \multicolumn{7}{|c|}{ 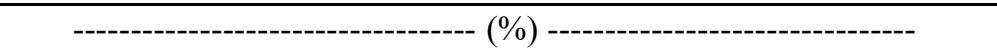 } & \\
\hline Jagung segar & 32,50 & 96,15 & 3,85 & 16,14 & 10,00 & 2,40 & 67,61 & 4521 \\
\hline Jambu Biji & 33,20 & 99,45 & 0,55 & 0,82 & 0,20 & 24,62 & 73,81 & 4426 \\
\hline Tauge & 12,05 & 94,48 & 5,52 & 3,91 & 0,41 & 19,60 & 70,56 & 4963 \\
\hline Pisang Kepok & 27,32 & 96,48 & 3,52 & 5,17 & 1,01 & 5,55 & 84,75 & 5133 \\
\hline Kelapa & 58,40 & 97,27 & 2,73 & 3,57 & 32,18 & 11,75 & 49,77 & 6340 \\
\hline Biji Bunga Matahari & 96,35 & 95,61 & 4,39 & 29,91 & 49,64 & 5,94 & 10,12 & 8313 \\
\hline Wortel & 24,67 & 91,08 & 8,92 & 10,21 & 0,20 & 1,09 & 79,58 & 3452 \\
\hline Pellet & 91,37 & 96.20 & 3,80 & 15,72 & 3,32 & 3,50 & 73,66 & 4353 \\
\hline Kacang Panjang & 37,63 & 93,53 & 6,47 & 2,93 & 1,05 & 1,76 & 87,79 & 4475 \\
\hline Kangkung & 14.10 & 88,30 & 11,70 & 33,63 & 0,44 & 1,10 & 53,13 & 4327 \\
\hline Telur ayam rebus & 31,13 & 96,38 & 3,62 & 54,79 & 31,71 & 0,75 & 9,17 & 6897 \\
\hline
\end{tabular}

$\mathrm{BK}=$ Berat Kering, $\mathrm{PK}=$ Protein Kasar, LK $=$ Lemak Kasar, $\mathrm{SK}=$ Serat Kasar, BETN $=$ Bahan Ekstrak Tanpa Nitrogen, GE = Gross Energy/ Energi Bruto.

\section{Konsumsi Pakan}

Biji-bijian dan buah-buahan merupakan jenis pakan yang disukai burung nuri bayan di alam, begitu pula di penangkaran. Selain jenis pakan, kualitas pakan juga menentukan palatabilitas pakan. Kualitas pakan ditentukan oleh nilai gizi yang terkandung dalam pakan tersebut (Soemadi \& Mutholib 1995). Jenis dan kandungan nutrien pakan nuri bayan di penangkaran yang diberikan selama penelitian tercantum pada Tabel 2. Adapun tingkat palatabilitas pakan tercantum dalam Tabel 3.
Bahan pakan yang digunakan dalam penelitian terdiri atas sumber karbohidrat, yaitu jagung segar dan pisang kepok; sumber lemak, yaitu kelapa; dan sumber protein, yaitu biji bunga matahari dan telur rebus. Sumber vitamin dan mineral diperoleh dari sayur dan buah-buahan seperti jambu biji, tauge, wortel, kacang panjang, dan kangkung. Jumlah rata-rata konsumsi pakan koloni burung nuri bayan kelompok kontrol dan perlakuan per hari ditampilkan dalam tabel 3 .

Tabel 3. Rataan Konsumsi Pakan Segar, Berat Kering, dan Proporsinya pada Nuri Bayan.

\begin{tabular}{|c|c|c|c|c|c|c|}
\hline \multirow{3}{*}{ Bahan pakan } & \multicolumn{4}{|c|}{ Konsumsi } & \multirow{2}{*}{\multicolumn{2}{|c|}{$\begin{array}{c}\text { Proporsi konsumsi } \\
\text { bahan kering } \\
(\%)\end{array}$}} \\
\hline & \multicolumn{2}{|c|}{$\begin{array}{l}\text { Bahan segar } \\
\text { (g/koloni/hari) }\end{array}$} & \multicolumn{2}{|c|}{$\begin{array}{c}\text { Bahan kering } \\
\text { (g/koloni/hari) }\end{array}$} & & \\
\hline & K0 & K1 & K0 & K1 & K0 & K1 \\
\hline Jagung segar & 110,53 & 119,20 & 35,92 & 38,74 & 24,73 & 25,07 \\
\hline Jambu Biji & 52,27 & 55,61 & 17,35 & 18,46 & 11,95 & 11,95 \\
\hline Biji Bunga Matahari & 34,74 & 36,87 & 34,17 & 36,26 & 23,53 & 23,46 \\
\hline Pisang Kepok & 42,43 & 46,34 & 11,59 & 12,66 & 7,98 & 8,19 \\
\hline Tauge & 18,76 & 18,92 & 2,26 & 2,28 & 1,56 & 1,48 \\
\hline Kelapa & 27,60 & 30,00 & 16,12 & 17,52 & 11,10 & 11,34 \\
\hline Wortel & 17,68 & 18,80 & 4,36 & 4,64 & 3,00 & 3,00 \\
\hline Kangkung & 19,70 & 19,78 & 2,78 & 2,79 & 1,91 & 1,80 \\
\hline Kacang Panjang & 17,43 & 17,68 & 6,56 & 6,65 & 4,52 & 4,30 \\
\hline Telur Ayam Rebus & 45,37 & 46,75 & 14,12 & 14,55 & 9,72 & 9,42 \\
\hline$\sum$ & 386,51 & 410,11 & 145,24 & 154,56 & 100,00 & 100,00 \\
\hline
\end{tabular}

Keterangan: $\mathrm{K} 0=$ Koloni terdiri dari satu bayan betina (1 tahun), tiga bayan betina ( 2 tahun), dan satu bayan jantan ( 2 tahun); K1 = Koloni terdiri dari satu bayan betina (1 tahun), tiga bayan betina ( 1 tahun), satu bayan jantan (2 tahun), dan satu bayan jantan (4 tahun). 
Berdasarkan rataan konsumsi pada tabel 3, tidak ada perbedaan urutan preferensi pada konsumsi bahan pakan baik pada K0 maupun K1. Pakan yang paling banyak dikonsumsi, yaitu jagung sebesar 110,53 g/koloni/hari pada K0 dan 119,20 g/koloni/hari pada K1, sedangkan pakan yang paling sedikit dikonsumsi, yaitu kacang panjang 17,43 g/ koloni/hari pada $\mathrm{K} 0$ dan 17,68 g/koloni/hari pada K1. Urutan bahan pakan yang paling banyak dikonsumsi hingga yang paling sedikit dikonsumsi sama baik pada K0 maupun $\mathrm{K} 1$, yaitu jagung, jambu, telur ayam rebus, pisang kepok, biji bunga matahari, kelapa, kangkong, tauge, wortel, dan kacang panjang. Pakan yang diberikan pada penelitian ini adalah pakan yang disukai oleh bayan dan juga memenuhi kriteria sebagai pakan yang dapat memenuhi kebutuhan nutrien dari burung bayan. Menurut McGuire \& Beerman (2012) nutrien adalah zat yang terkandung dalam suatu makanan yang dibutuhkan atau digunakan oleh tubuh sebagai energi, struktur, regulasi atau reaksi kimia. Jumlah pakan yang dikonsumsi mencerminkan kebutuhan nutrien burung bayan tersebut. Selain itu, jumlah pakan yang dikonsumsi sehari dipengaruhi oleh umur burung. Burung dewasa akan mengonsumsi pakan sekitar $10-40 \%$ dari berat tubuhnya, sedangkan anak burung sebanyak berat tubuhnya sendiri dalam sehari (Prahara 1998). Jika dilihat jumlah pakan yang dikonsumsi pada $\mathrm{K} 0$ sebesar 386,51 g/koloni/ hari, maka jika dibagi jumlah individu pada K0, rata-rata per ekor mengkonsumsi pakan seberat 77,30 g/ekor/hari. Sementara untuk K1 sebesar 410,11 g/koloni/hari, jika dibagi jumlah individu pada $\mathrm{K} 1$, maka rata-rata per ekor mengonsumsi pakan sebanyak 68,35 g/ ekor/hari g/ekor/hari. Seekor burung bayan dewasa memiliki berat 375-610 g (Arndt 1986). Berat burung bayan yang digunakan dalam penelitian ini sekitar 250-300 g. Jadi, konsumsi pakan burung bayan dalam penelitian ini sekitar $20-30 \%$ berat tubuhnya. Konsumsi rata-rata per ekor pada K1 lebih rendah dibandingkan $\mathrm{K} 0$. Hal ini dimungkinkan karena penambahan jantan yang berpengaruh terhadap perilaku makan koloni tersebut karena adanya dominansi dari jantan yang baru. Sebagaimana yang dikemukakan oleh Verhulst (2014) bahwa dominansi meningkat seiring bertambahnya usia individu.

\section{KESIMPULAN}

Frekuensi perilaku harian tertinggi nuri bayan di penangkaran pada koloni kontrol (K0) dan koloni perlakuan (K1) adalah bertengger, sedangkan frekuensi perilaku terendah adalah eliminasi. Frekuensi perilaku eliminasi, vokalisasi, berjalan, dan merawat tubuh lebih tinggi pada K0 daripada K1. Tidak terdapat perbedaan preferensi pakan antara $\mathrm{K} 0$ dan K1. Konsumsi pakan yang paling tinggi adalah jagung segar sebagai sumber energi. Pakan yang lebih disukai sebagai sumber protein, yaitu telur rebus dibandingkan dengan biji bunga matahari. Untuk kategori buah dan sayur yang paling disukai, yaitu jambu biji.

\section{UCAPAN TERIMA KASIH}

Terima kasih penulis ucapkan kepada seluruh teknisi penangkaran burung dan Laboratorium Pengujian Nutrisi Pusat Penelitian Biologi-LIPI atas bantuannya selama proses penelitian ini berlangsung.

\section{DAFTAR PUSTAKA}

Alamendah. (2011). Pohon Winong atau Binong (Tetrameles nudiflora). http:// 
www.alamendah.org/2011/04/22/

pohon-winong-atau-binong- tetrameles -nudiflora/.

Alikodra HS. 1990. Pengelolaan Fauna. Jilid I. Bogor: PAU-IPB.

Altmann, J. (1974). Observational Study of Behaviour: Sampling Methods. Behaviour. Leiden: Brill

Arndt, T. (1986). Parrots: their life in the wild. Bromlitz: Horst Muller-Verlag Walsrode.

Ashokkumar, K., Elayabalan, S., Shobana, V.G., Sivakumar, P., \& Pandiyan, M. (2018). Nutritional value of cultivars of Banana (Musa spp.) and its future prospects. Journal of Pharmacognosy and Phytochemistry, 7(3), 2972-2977.

Bailey. 1984. Principles of Wildlife Management. New York: John Wiley \& Sons.

Beehler, B.M., Pratt, T.K., \& Zimmerman, D.A. (2001). Burung-Burung di Kawasan Papua. Bogor: Puslitbang Biologi-LIPI.

Beissinger S.R. \& Bucher E.H. (1992). Sustainable harvesting of parrots for conservation pp 73-115. In Beissinger, S.R. \& Sayder, N.F.R. (Eds) New World parrots in crisis: solutions from conservation biologi. Washington DC: Smithsonian Institution Press.

Carrete, M. \& Tella, J.L. (2015). Rapid loss of antipredatory behaviour in captivebred birds is linked to current avian invasions. Scientific Reports, 5(1), 1-8.

Desmudzat, A.S., Sukandar, P., \& Suryanda, A. (2015). Perbandingan perilaku harian burung bayan jantan (Eclectus roratus Müller, 1776) berdasarkan keberadaan pejantan pesaing di Taman Margasatwa Ragunan. Bioma, 12(1), 67-72.

Forshaw, J.M. \& Cooper, W.T. (1989). Parrots of The World. Australia: Lansdowne
Editions.

Forshaw J. (2010). Parrots of the World. Neptune, New Jersey: Princeton University Press.

Garsetiasih, R. \& Takandjandji, M. (2006). Konsumsi dan Palatabilitas Pakan Burung Bayan Sumba (Eclectus roratus cornelia Bonaparte) di Penangkaran. Jurnal Penelitian Hutan dan Konservasi Alam, 3 (1), 75-82.

Gill, F., Donsker, D., \& Rasmussen, P. (Eds). (2020). IOC World Bird List (v10.2). doi:10.14344/IOC.ML.10.2. https:// www.worldbirdnames.org/. [Diakses 1 Juli 2021].

Heinsohn R, Legge S. 2003. Breeding biology of the reverse-dichromatic, cooperative parrot Eclectus roratus. Journal of Zoology, 259, 197-208.

Homberger, D.G. (2006). Classification and status of wild populations of parrots. In Andrew U. Luescher (Ed.) Manual of parrot behavior. USA: Blackwell Publishing.

BirdLife International. (2019). Eclectus roratus. The IUCN Red List of Threatened Species 2019: e.T155072212A155636053. https:// dx.doi.org/10.2305/IUCN.UK.20193.RLTS.T155072212A155636053.en.

Downloaded on 21 July 2021.

Juniper, T. \& Parr, M. (1998). Parrots: A Guide to the Parrots of the World. Robertsbridge: Pica Press.

Kartikasari, S.N., Marshall, A.J., \& Beehler, B. (2007). Ekologi Papua (No 6). Jakarta: Yayasan Pustaka Obor Indonesia.

Kuang, H., Yang, F., Zhang, Y., Wang, T., \& Chen, G. (2018). The Impact of Egg Nutrient 
Composition and Its Consumption on Cholesterol Homeostasis. Cholesterol, 2018, 6303810.https://oi.org/10.1155/2018/6303810

Magno, M.N. (2015). Housing, Environment, and Public Awareness. Avian Medicine. Missouri: Elsevier

Martin, P. \& Bateson, P. (2007). Measuring behavior introductory guide. Third edition. Sydney: Cambridge University Press.

McGuire, M. \& Beerman, K.A. (2012). Nutritional sciences: From fundamentals to food. Belmont, CA: Thomson/ Wadsworth.

Minias, P., Gach, K., Włodarczyk, R., Bartos, M., Drzewińska- Chańko, J., Rembowski, M., Jakubas, D., \& Janiszewski, T. (2020). Colony size as a predictor of breeding behaviour in a common waterbird. Plos one, 15(11), e0241602.

Nurhakim, S. \& Abdurohman, D. (2014).

Dunia Burung dan Serangga: Mengenal Fakta Sains dan Keunikannya. Jakarta: Bestari.

Prahara, W. (1998). Sukses Memelihara Burung. Jakarta: Penebar Swadaya.

Prijono, S.N., Masyud, B., Rachmatika, R., \& Suparno. (2020). Burung Bayan (Eclectus roratus): Bioekologi, Pakan, Reproduksi dan Pelestariannya. Bogor: IPB Press.

Revilia, W., Nugroho, A., \& Kaswinarni, F. (2017). Aktivitas Burung Nuri Bayan (Eclectus roratus) di Wildlife Rescue Centre Kulon Progo Yogyakarta. Semnas Sains \& Entrepreneurship IV (pp. 534-542). Semarang: Program Studi Pendidikan Biologi, Universitas PGRI Semarang.

Soemadi, W. \& Mutholib, A. (1995). Pakan burung. Jakarta: Penebar Swadaya.

Setyowati, A.B., Sreiyanto, A., Asma, A.W., Santosa, A., Aliadi, A., Steni, B., Wulandari, C., Indraswati, E., Hanif, F., Alexander, H., Arsyad, I., Adi, N., Nurmawanti, S., Ramono, W., \& Sukmantoro, W. (2008). Konservasi Indonesia-Sebuah Potret Pengelolaan dan Kebijakan. Jakarta: Pokja Kebijakan Konservasi.

Takandjandji, M., Kayat, K., \& Njurumana, G.N.D. (2010). Perilaku Burung Bayan Sumba (Eclectus roratus cornelia Bonaparte) di Penangkaran Hambala, Sumba Timur, Nusa Tenggara Timur. Jurnal Penelitian Hutan dan Konservasi Alam, 7(4), 357-369.

Takandjanji, M. \& Sutrisno, E. (2011). Keberhasilan pelestarian ex-situ burung bayan sumba (Eclectus roratus cornelia). Prosiding Ekspose/HasilHasil Penelitian BPK Kupang.

Van Balen, B., Kilmaskossu, A., \& Puradyatmika, P. (2015). A Guide to The Birds of The Mimika Region Papua, Indonesia. Papua: PT Freeport Indonesia.

Verhulst, S., Geerdink, M., Salomons, H.M., \& Boonekamp, J.J. (2014). Social life histories: jackdaw dominance increases with age, terminally declines and shortens lifespan. Proceedings of the Royal Society B: Biological Sciences, 281(1791), 20141045.

Warsito, H. \& Bismark, M. (2010). Penyebaran dan Populasi Burung Paruh Bengkok pada Beberapa Tipe Habitat di Papua. Jurnal Penelitian Hutan dan Konservasi Alam, 7(1), $93-$ 102. 